\title{
Company Image as an Employer on Poland's Mobile Telecommunication Market and Its Relationship with Consumer Recommendations
}

\author{
Maria Rybaczewska, Łukasz Sułkowski
}

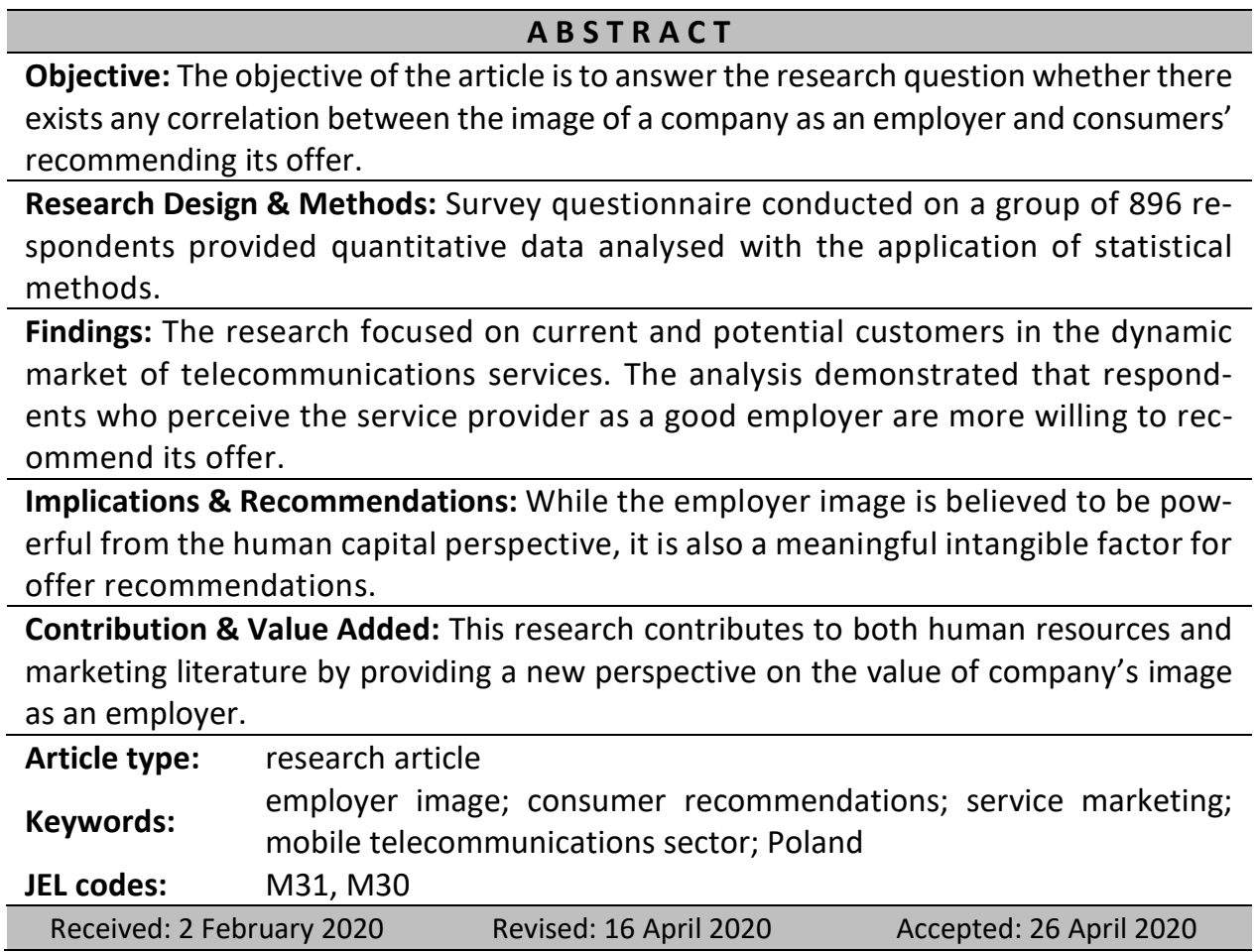

Suggested citation:

Rybaczewska, M., Sułkowski, Ł. (2020). Company Image as an Employer on Poland's Mobile Telecommunication Market and Its Relationship with Consumer Recommendations. Entrepreneurial Business and Economics Review, 8(2), 141-152. https://doi.org/10.15678/EBER.2020.080208 


\section{INTRODUCTION}

As Lievens and Slaughter (2016) suggest, while employer image is a topic that has been analysed in the literature, more insight and new perspectives are still needed. This article aims to contribute towards this by investigating consumer recommendations. The power of company image as an employer is underlined in the context of numerous sectors, e.g. tourism (Bednarska \& Olszewski, 2013; Jakab \& Happ, 2017), nursing (Van Hoye, 2008), or retail (Keeling, McGoldrick, \& Sadhu, 2013). The literature explicitly emphasises its meaning and power in the context of human resources, including applicant attraction (Uggerslev, Fassina, \& Kraichy, 2012), recruitment (Moss \& Tilly, 2003), and job satisfaction and engagement (Helm, 2013). What follows is that employer image is frequently perceived as the moderator of the quality of service offered to final customers (App, Merk, \& Buttgen, 2012). The relationship of employer image with consumers remains under researched. Therefore, we address the dimension of customer-based brand equity in this context. To the best of our knowledge, this article belongs to one of the first attempts to explore the power of a company's external image as an employer in terms of customer recommendations of its offer. We consider whether the positive image of a company as an employer motivates its customers to recommend its offer. Such an approach reveals the shared goals and benefits for human resources, retail, and marketing connected with the positive employer image. Thus, the theoretical implications and practical applications resulting from this article are wide and discussed further in the conclusions.

The article includes several sections: the introduction is followed by the literature review, which presents the current state of the art in the analysed field and highlights the addressed gaps in knowledge. Material and methods explain and justify the applied research approach, including primary data and their quantitative analysis. The results and discussion section focuses on the presentation and contextualisation of findings within the field, followed by conclusions that address the theoretical implications and managerial applications of the research outcome, including also research limitations and future recommendations.

\section{LITERATURE REVIEW}

The significance of competitive advantage is growing, especially from the perspective of market competition, which is dynamically increasing (e.g. Gebauer, Gustafsson, \& Witell, 2011; Štůsek, Kubata, \& Očenášek, 2017; Fertö, 2018). Such a situation on the market produces easy offer duplication processes - depending on the sector but observed in various contexts - which lead to the 'sameness' of available offers and difficulties with purchase decisions (Skawińska, 2010). Environment like that underpins the necessity to seek supplementary motivation for target groups to choose a particular offer.

Tangible indicators like offer and price (e.g. mentioned by Djatmiko \& Pradana, 2016; Kotler \& Armstrong, 2010) and intangible factors - such as marketing campaigns, loyalty, image as a service/product provider (e.g. mentioned Liu, 2007; Saeidi et al., 2015; Alic, Agic, \& Cinjarevic, 2017) - provide such reasons both directly and indirectly; that is, via the subjective external image of the company as an employer or as a moderator of the will to recommend the company's offer. Word-of-mouth marketing (specifically recommendations) may play a role of the 'detail' the changes the final purchase decision, especially when all 
options seem to be equally available and attractive. Literature underlines the meaning of offer recommendations (East, Hammond, \& Lomax, 2008; Lin \& Lu, 2010; Kim \& Chao, 2019), but until now it has concentrated on the general image of the company or its image as a producer or service provider (Balmer, \& Greyser, 2006; Diallo, 2012). The number of studies on offer recommendations has increased over the recent years and increasingly refers to intellectual products, networks, and social networking sites (Puncheva-Michelotti, Hudson, \& Jin, 2018; Tsimonis, Dimitriadis, \& Omar, 2019; D'lima, 2018; MacGregor, Pelikánová, \& Cvik, 2018; Lenart-Gansiniec, \& Sułkowski, 2018; Csordás, 2020).

While corporate social responsibility aspects are discussed in the literature (Aguinis \& Glavas, 2012; Carroll \& Shabana, 2010; Fernandez-Kranz \& Santalo, 2010; Flammer, 2015), not much attention is directed to company image as an employer from the consumers' standpoint. Scholars usually focus on human resources aspects, as this element is considered the most direct and powerful in this context (e.g. Uggerslev, Fassina, \& Kraichy, 2012). However, other approaches might provide a more holistic understanding and new insights of the matter. The perspective of consumers' recommendations has been neglected in research so far. Moreover, the overall brand equity topic is only rarely contextualised within the human resources field. A paper by Anselmsson, Bondesson, and Melin (2016) who study retail customers' interests in HRM and employer branding - is an exception that emphasises the existing gap in knowledge. Our study contributes towards bridging the gap identified by Anselmsson, Bondesson, and Melin (2016), since we address customer recommendations in the service sector (considering its peculiarity) and the interdependencies between the image of the service provider as an employer and word-of-mouth marketing among its customers. Therefore, this article joins two powerful concepts, primarily connected with separate fields of human resources and marketing, to test the existence of shared goals and benefits. We hypothesise that a positive external image of the company as an employer enhances consumer recommendations for that company. On the basis of the above literature, we formulated the following hypothesis:

H: The positive company image as an employer on Poland's mobile telecommunication market motivates its users to recommend its offer.

\section{MATERIAL AND METHODS}

The mobile telecommunications market was chosen for this study due to several reasons, including its reputation for being dynamic, modern, and very active in the field of Corporate Social Responsibility (CSR) and marketing campaigns (Dornisch, 2001; Sánchez \& Asimakopoulos, 2012). Moreover, this market is unified by laws and regulations, which effects in similarities of prices and conditions of offered services. Furthermore, the Polish context of an economy transformed after a transition process underpins consumer sensitiveness to intangible (marketing) criteria; this is particularly explicit in the context of the commonly used mobile telecommunications services: relatively new and highly desired technologies.

In Poland, this sector consists of four main mobile network operators - Polkomtel, P4, Orange Poland, and T-Mobile Poland - and many mobile virtual network operators connected with the four main ones; e.g. Netia connected with P4 or Sferia connected with Polkomtel. Since our research focused on the users in the context of the four main mobile 
network operators, we follow the names commonly presented in the marketing campaigns, i.e. the names of four main networks: Plus (instead of Polkomtel), Play (instead of P4), Orange (instead of Orange Poland), and T-Mobile (instead of T-Mobile Poland). Moreover, we should note that the full names of the operators are often unknown to the users.

Whereas we recognise the benefits of an in-depth qualitative investigation, it remains a task for the future (Bryman \& Bell, 2015). In this study, we chose the quantitative approach to receive the overall picture of correspondences between the company image as an employer and customer recommendations. Such an approach was confirmed to be beneficial by a pilot questionnaire study conducted in 2013 on a group of 100 respondents studying in Lodz. This also contributed to the structure and the final form of the questionnaire.

The second stage of primary research was conducted on a group of 896 respondents who use mobile telecommunications services in Poland and do not working for any of the providers; the high response rate resulted from face-to-face method applied by trained pollsters, which equalled $92 \%$, i.e. 824 survey analysed questionnaires. To ensure that the returned questionnaires were representative of the wider population group characteristics, the respondents were chosen according to simple random sampling, while data was tested against census data. The survey questionnaire provided data concerning, among other things, the respondents' perception of the mobile telecommunications service providers as employers and the respondents' will to recommend the services offered by their provider.

To verify the assumed hypothesis, we applied such statistical calculations as the analysis of variance, the T-student test, the Bonferroni correlation, and the Games-Howell correction.

\section{RESULTS AND DISCUSSION}

Research Sample included both female $(52.1 \%)$ and male $(47.9 \%)$ inhabitants of three voivodeships in Poland: Mazowieckie (53\%), Lodzkie (26\%), and Kujawsko-Pomorskie (21\%). All of them were divided into four age categories: below 20 years old, 20-40 years old, 41-60 years old, and over 60 years old (as shows Figure 1). Furthermore, we established four categories of personal professional circumstances: student, employed person, unemployed person, and pensioner (Figure 2); and five categories of net monthly income per person in the household: below 1000 PLN, 1000-1500 PLN, 1501-2000 PLN, 2001-3000 PLN, over 3000 PLN (Figure 3).

Figure 2 reveals that Plus is the most popular mobile telecommunications service provider among students (34.4\% of respondents), the unemployed group $140.9 \%$ of respondents), and pensioners (42.6\% of respondents). Orange is the leading service provider among the employed persons (31.8\% of respondents).

Figure 3 shows that Orange and Plus are the most popular mobile telecommunications service providers among the respondents with the highest income, while Plus managed to attract also the respondents with the lowest income but not Orange. T-Mobile is the leading provider among the respondents with the monthly net income per person at the level between 1501-2000 PLN.

The study revealed differences in the perception of mobile telecommunications service providers in Poland as employers. Respondents described their opinion about each of the four networks on a five-point Likert scale, from 1 to 5 , in which 1 means very negative and 5 means very positive. The most positive average perception of company image as an 
employer among all respondents was achieved by T-Mobile (3.13) and the worst by Plus (3.05), but they were all relatively close (Figure 1 ).

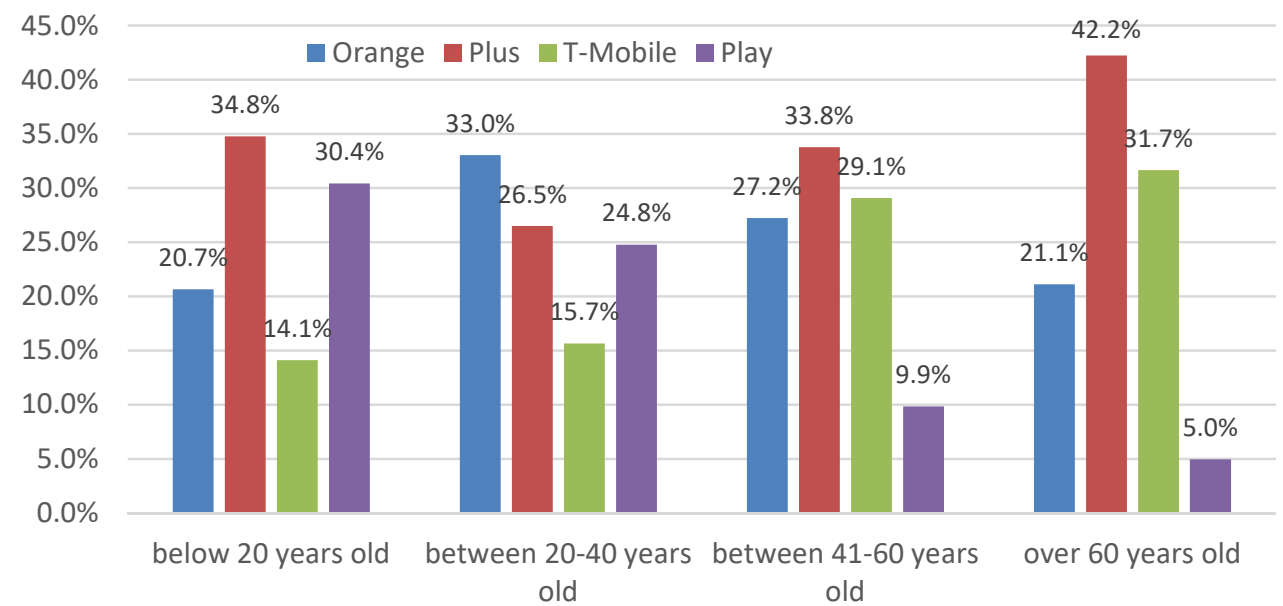

Figure 1. Age characteristics of respondents by their service provider Source: own survey $(n=824)$.

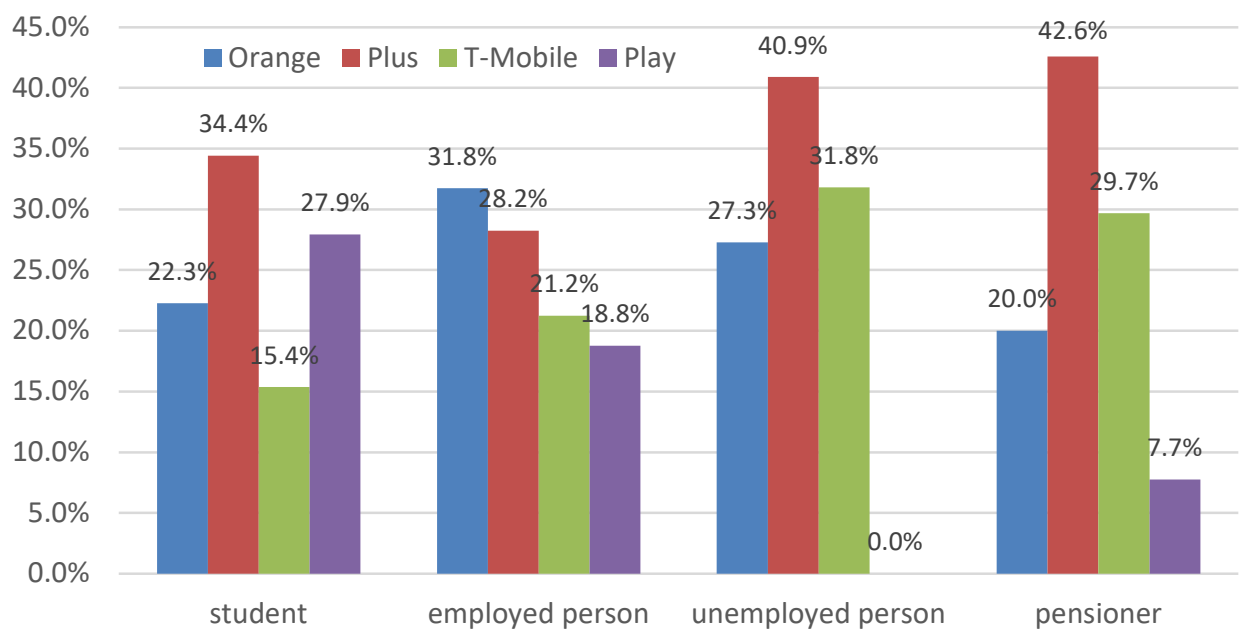

Figure 2. Professional circumstances of respondents by their service provider Source: own survey $(n=824)$.

A more explicit diversity appears among users of particular network services. The most positive average perception of company image as an employer is achieved by T-Mobile (3.52 among its users), whereas Plus received 3.22. In every case the opinion about the provider as an employer was more positive among users than among non-users. The T-student test showed that these differences were statistically significant $(p<0.001)$. 


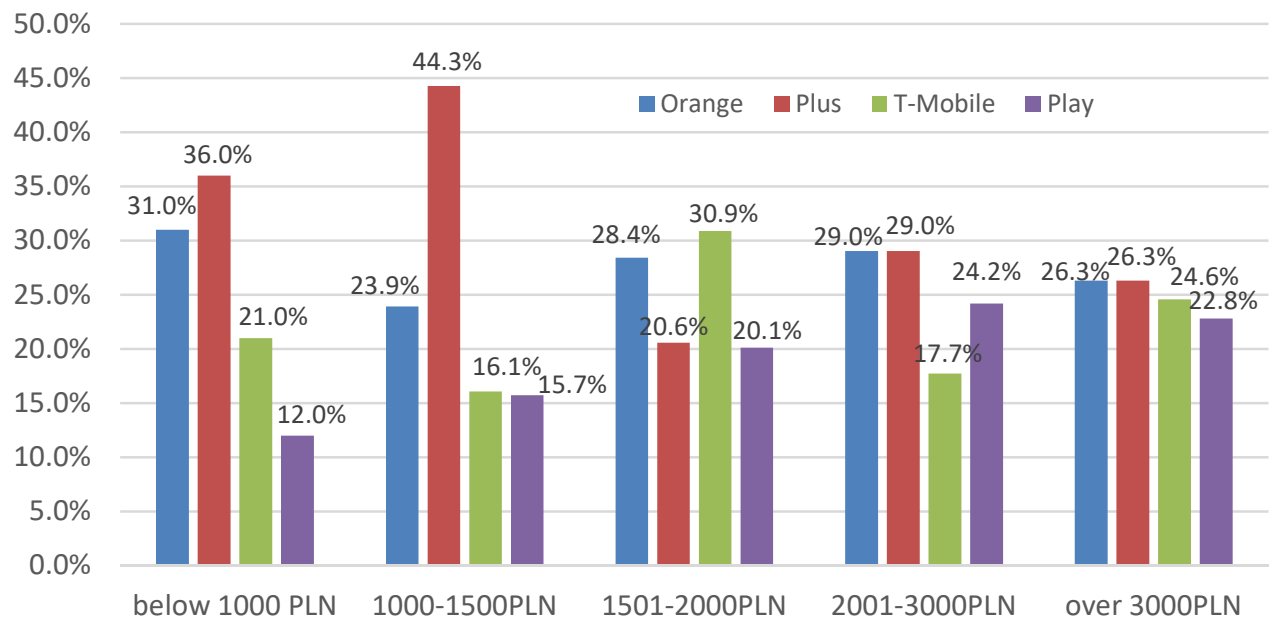

Figure 3. Net monthly income per person of respondents by their service provider Source: own survey $(n=824)$.

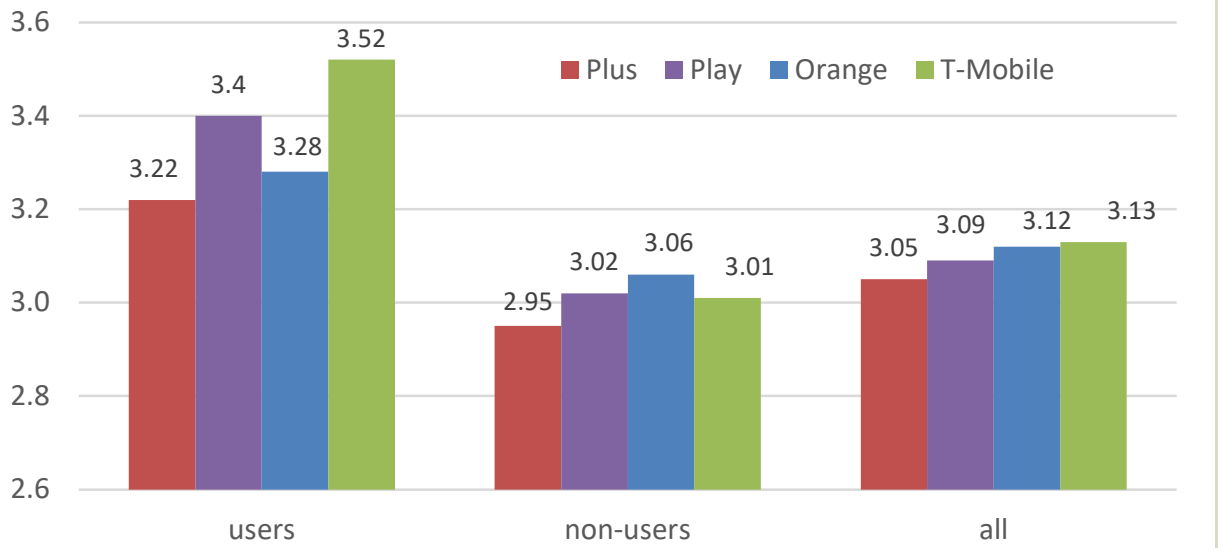

Figure 4. The average respondents' perception of Poland's four leading networks image as employers Source: own survey $(n=824)$.

Data revealed that the most frequently recommended mobile telecommunications network by the respondents who are its users is Play (2.88). The least recommended company is T-Mobile (2.37), as shown in Figure 2.

In further analysis, company image as an employer was described as positive, neutral, and negative with a five-point Likert-scale data gathered from the respondents. We tested the hypothesis that positive company image as an employer enhances its users to recommend its offer in the context of the four mobile telecommunications service providers. Descriptive statistics concerning the conducted investigation are available in Table 1. Investigation incorporated a between groups analysis of variance, using the frequency of 
recommendations as a dependent variable and employer image as an independent variable, which was conducted for every company.

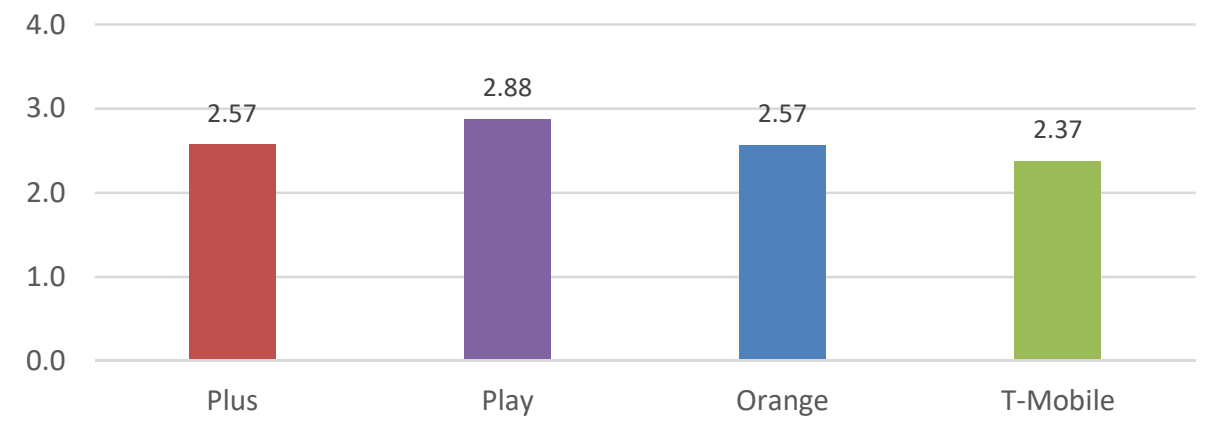

Figure 5. The average frequency of respondents' recommending of the services of their current network Source: own survey $(n=824)$.

Table 1. The average frequency of network recommendation by its users in terms of its perception as an employer

\begin{tabular}{|l|c|c|c|}
\hline Perception of the company as an employer & \multicolumn{2}{|l|}{ Mean } & Standard deviation \\
\hline \multirow{4}{*}{ Plus } & Negative & 1.80 & 1.34 \\
\cline { 2 - 4 } & Neutral & 2.62 & 1.25 \\
\cline { 2 - 4 } & Positive & 3.15 & 1.29 \\
\hline \multirow{4}{*}{ Play } & Negative & 1.94 & 1.59 \\
\cline { 2 - 4 } & Neutral & 2.91 & 1.33 \\
\cline { 2 - 4 } & Positive & 3.52 & 1.39 \\
\hline \multirow{3}{*}{ Orange } & Negative & 1.87 & 1.22 \\
\cline { 2 - 4 } & Neutral & 2.61 & 1.17 \\
\cline { 2 - 4 } & Positive & 3.03 & 1.15 \\
\cline { 2 - 4 } & Negative & 2.33 & 0.91 \\
\cline { 2 - 4 } & Neutral & 1.88 & 1.18 \\
\cline { 2 - 4 } & Positive & 3.08 & 1.47 \\
\hline
\end{tabular}

Based on a five-point Likert scale, in which 1 means never and 5 means very often. Source: own survey $(n=824)$.

As shows Table 2, in the case of Plus the analysis revealed a statistically significant main effect: $F(2,294)=20.67 ; p<0.001$. Multiple tests (with the application of the Bonferroni correction) showed that the participants who positively perceive Plus as the employer and are its users recommend it more frequently than those who neutrally perceive Plus as the employer $(p=0.005)$ and more often than those who negatively perceive Plus as the employer( $p$ $<0.001)$. Moreover, persons who neutrally perceive Plus as the employer and are its users recommend it more frequently than persons who have a negative opinion of Plus as an employer $(p<0.001)$. In the case of Play, the analysis of variance proved a statistically significant main effect of $F(2,169)=9.75, p<0.001$, while multiple tests provided findings similar to Plus ( $p=0.022, p=0.002$, and $p=0.021$, respectively). In the case of Orange, the analysis of variance revealed a statistically significant main effect of $F(2,243)=11.92, p<0.001$, while the results of multiple tests corresponded to those of Plus and Play $(p=0.026$ and $p<0.001$; 
$p=0.007$, respectively). The analysis of variance concerning the context of T-Mobile provided a statistically significant main effect: $F(2,191)=18.53 ; p<0.001$. Multiple tests (with the application of the Games-Howell correction) showed results similar to three other networks with only one exception ( $p<0.001, p=0.020$, and $p=0.185$, respectively). In other words, users who positively perceive the image of investigated companies as employers differed from the users who neutrally and negatively perceive this image in terms of offer recommendations. If one believes a company has a good image of employment, they are more likely to be positive in recommending the company's products/ services.

Table 2. The results of the one-way analysis of variance concerning consumer recommendations in the context of Plus, Play, Orange, and T-Mobile

\begin{tabular}{|c|c|c|c|c|c|c|}
\hline & Brands & $\begin{array}{l}\text { Sum of } \\
\text { squares }\end{array}$ & df & Mean square & $\mathbf{F}$ & Significance \\
\hline \multirow{3}{*}{ Plus } & Between groups & 67.919 & 2 & 33.959 & 20.668 & 0.000 \\
\hline & Within Groups & 483.078 & 294 & 1.643 & & \\
\hline & Total & 550.997 & 296 & & & \\
\hline \multirow{3}{*}{ Play } & Between groups & 37.122 & 2 & 18.561 & \multirow[t]{3}{*}{9.750} & \multirow[t]{3}{*}{0.000} \\
\hline & Within Groups & 321.733 & 169 & 1.904 & & \\
\hline & Total & 358.855 & 171 & & & \\
\hline \multirow{3}{*}{ Orange } & Between groups & 32.608 & 2 & 16.304 & \multirow[t]{3}{*}{11.923} & \multirow[t]{3}{*}{0.000} \\
\hline & Within Groups & 332.290 & 243 & 1.367 & & \\
\hline & Total & 364.898 & 245 & & & \\
\hline \multirow{3}{*}{ T-Mobile } & Between groups & 63.125 & 2 & 31.562 & \multirow[t]{3}{*}{18.532} & \multirow[t]{3}{*}{0.000} \\
\hline & Within Groups & 325.293 & 191 & 1.703 & & \\
\hline & Total & 388.418 & 193 & & & \\
\hline
\end{tabular}

Source: own survey $(n=824)$.

While the average perception of Poland's mobile telecommunications companies as employers does not differ much, we observe far larger and statistically significant dissimilarities among service users and non-users. This might result from the phenomenon described, among others, by Brooks (2011) as confirmation bias; which concerns both tangible and intangible characteristics of the chosen provider. Irrespective of its origin, the confirmation bias encourages buyers to be more committed to the company. Moreover, these observations correspond with suggestions widely presented in the literature that a company's perception is connected with its values - including respect for employees and how they are treated - especially in the context of growing CSR awareness among the buyers (Carroll \& Shabana, 2010; Fernandez-Kranz \& Santalo, 2010; Flammer, 2015). This study proves that the meaning of employer image should not be restricted to human resources aspects, as its exploration should include the marketing perspective.

We positively verified the tested hypothesis - that the positive company image as an employer motivates its users to recommend its offer- in the context of all four leading mobile telecommunications networks in Poland, i.e. Plus, Play, Orange, and T-Mobile. Therefore, we proved that the image of a company as an employer is a significant stimulus increasing the positive word-of-mouth marketing as it moderates the frequency of recommendations and, assumedly, the users' will to recommend a company. The significance of this result is reinforced by the current situation on the market, i.e. very strong and still rapidly growing competition and the growing 'sameness' of available offers (Lin \& Lu, 
2010; Sánchez \& Asimakopoulos, 2012; Skawińska, 2010). While product/ company recommendations as a meaningful, complex, and interdisciplinary concept have been investigated in the marketing literature (Sheppard, Hartwick, \& Warshaw, 1988), further studies, especially introducing new dimensions, are still needed. Our research showed that we should include human resources aspects in such dimensions.

\section{CONCLUSIONS}

The research concludes that the linking of two concepts - in the literature connected primarily with separate fields of human resources (employer image) and marketing (consumer recommendations) - develops their understanding. For practitioners, such an approach also contributes towards the exploration of shared benefits and goals, in most cases focused on different perspectives. Moreover, this study provides not only the conclusion of existence of these shared interests but also presents a way to stimulate them.

The proposed approach of linking human resources and marketing aspects can contribute to the desired differentiation between competitors on the market and play a decisive role during a purchase decision process. Furthermore, its added value for practitioners is associated with encouragement to information sharing with consumers. Therefore, this study provides new insights on investments connected with intangible assets development, i.e. activities in employer image building and strengthening.

This study, as any other, has also its limitations. It was conducted in the specific context of the Poland's mobile telecommunications market. There is still a need to test the formulated hypothesis in other places, countries with different consumer sensitivity to marketing stimuli and social responsibility aspects.

We see a potential for further research in this field, as it is worth considering a study to test whether the obtained results are sector-dependent. Hence, cross-country and cross-sector analyses remain tasks for future research. Moreover, the obtained results encourage a longitudinal study to identify the trends and tendencies over time concerning the enhancement of recommendations by a company's positive image as an employer.

\section{REFERENCES}

Aguinis, H., \& Glavas, A. (2012). What We Know and Don't Know About Corporate Social Responsibility: A Review and Research Agenda. Journal of Management, 38(4), 932-968. https://doi.org/10.1177/0149206311436079

Alic, A., Agic, E., \& Cinjarevic, M. (2017). The Importance of Store Image and Retail Service Quality in Private Brand Image-Building. Entrepreneurial Business and Economics Review, 5(1), 27-42. https://doi.org/10.15678/eber.2017.050102

Anselmsson, J., Bondesson, N., \& Melin, F. (2016). Customer-based brand equity and human resource management image: Do retail customers really care about HRM and the employer brand?. European Journal of Marketing, 50(7/8), 1185-1208.

App, S., Merk, J., \& Buttgen, M. (2012). Employer Branding: Sustainable HRM as a Competitive Advantage in the Market for High-Quality Employees. Management Revue, 23(3), 262-278. https://doi.org/10.1688/1861-9908_mrev_2012_03_App 
Balmer, J.M., \& Greyser, S.A. (2006). Corporate marketing: Integrating corporate identity, corporate branding, corporate communications, corporate image and corporate reputation. European Journal of Marketing, 40(7/8), 730-741.

Bednarska, M.A., \& Olszewski, M. (2013). Organisational Determinants Of Employer Image: A Case Of The Tourism Industry In Poland. Anuario Turismo Y Sociedad, 14, 17-31.

Brooks, M.E. (2011). Management indecision. Management Decision, 49(5), 683-693. https://doi.org/10.1108/00251741111130788

Bryman, A., \& Bell, E. (2015). Business research methods: Oxford University Press, USA.

Carroll, A.B., \& Shabana, K.M. (2010). The Business Case for Corporate Social Responsibility: A Review of Concepts, Research and Practice. International Journal of Management Reviews, 12(1), 85-105. https://doi.org/10.1111/j.1468-2370.2009.00275.x

Csordás, A. (2020). Diversifying Effect of Digital Competence. AGRIS on-line Papers in Economics and Informatics, 12(1), 3-13. https://doi.org/10.7160/aol.2020.120101

Diallo, M.F. (2012). Effects of store image and store brand price-image on store brand purchase intention: Application to an emerging market. Journal of Retailing and Consumer Services, 19(3), 360-367.

Djatmiko, T., \& Pradana, R. (2016). Brand Image and Product Price; Its Impact for Samsung Smartphone Purchasing Decision. Procedia - Social and Behavioral Sciences, 219, 221-227. https://doi.org/10.1016/j.sbspro.2016.05.009

Dornisch, D. (2001). Competitive dynamics in Polish telecommunications, 1990-2000: growth, regulation, and privatization of an infrastructural multi-network. Telecommunications Policy, 25(6), 381-407.

East, R., Hammond, K., \& Lomax, W. (2008). Measuring the impact of positive and negative word of mouth on brand purchase probability. International Journal of Research in Marketing, 25(3), 215-224.

Fernandez-Kranz, D., \& Santalo, J. (2010). When Necessity Becomes A Virtue: The Effect Of Product Market Competition On Corporate Social Responsibility. Journal of Economics \& Management Strategy, 19(2), 453-487.

Fertö, I. (2018). Global Agri-food Trade Competitiveness: Gross Versus Value Added Exports. AGRIS online Papers in Economics and Informatics, 10(4), 39-47. https://doi.org/10.7160/aol.2018.100404

Flammer, C. (2015). Does product market competition foster corporate social responsibility? Evidence from trade liberalization. Strategic Management Journal, 36(10), 1469-1485. https://doi.org/10.1002/smj.2307

Gebauer, H., Gustafsson, A., \& Witell, L. (2011). Competitive advantage through service differentiation by manufacturing companies. Journal of Business Research, 64(12), 1270-1280. https://doi.org/10.1016/j.jbusres.2011.01.015

Helm, S. (2013). A Matter of Reputation and Pride: Associations between Perceived External Reputation, Pride in Membership, Job Satisfaction and Turnover Intentions. British Journal of Management, 24(4), 542-556. https://doi.org/10.1111/j.1467-8551.2012.00827.x

Jakab, P., Happ, É. (2017), Impact Assessment between the City and the Company Reputation, Economics and Sociology, Vol. 10, No. 1, 279-289. https://doi.org/10.14254/2071-789X.2017/10-1/

Keeling, K.A., McGoldrick, P.J., \& Sadhu, H. (2013). Staff Word-of-Mouth (SWOM) and retail employee recruitment. Journal of Retailing, 89(1), 88-104. https://doi.org/10.1016/j.jretai.2012.11.003

Kim, R. B., \& Chao, Y. (2019). Effects of brand experience, brand image and brand trust on brand building process: The case of Chinese millennial generation consumers. Journal of International Studies, 12(3), 9-21. https://doi.org/10.14254/2071-8330.2019/12-3/1 
Kotler, P., \& Armstrong, G. (2010). Principles of marketing. Pearson Education.

Lenart-Gansiniec, R., Sułkowski, Ł. (2018). Crowdsourcing - A New Paradigm of Organizational Learning of Public Organizations. Sustainability, 10(10), 3359. https://doi.org/10.3390/su10103359

Lievens, F., \& Slaughter, J.E. (2016). Employer Image and Employer Branding: What We Know and What We Need to Know. In F.P. Morgeson (Ed.), Annual Review of Organizational Psychology and Organizational Behavior (pp. 407-440). Palo Alto: Annual Reviews.

Lin, L.-Y., \& Lu, C.-Y. (2010). The influence of corporate image, relationship marketing, and trust on purchase intention: the moderating effects of word-of-mouth. Tourism Review, 65(3), 16-34.

Liu, Y. (2007). The long-term impact of loyalty programs on consumer purchase behavior and loyalty. Journal of Marketing, 71(4), 19-35.

Moss, P., \& Tilly, C. (2003). Stories employers tell: Race, skill, and hiring in America. Russell Sage Foundation.

Saeidi, S P., Sofian, S., Saeidi, P., Saeidi, S.P., \& Saaeidi, S.A. (2015). How does corporate social responsibility contribute to firm financial performance? The mediating role of competitive advantage, reputation, and customer satisfaction. Journal of Business Research, 68(2), 341-350. https://doi.org/10.1016/j.jbusres.2014.06.024

Sánchez, B.U., \& Asimakopoulos, G. (2012). Regulation and competition in the European mobile communications industry: An examination of the implementation of mobile number portability. Telecommunications Policy, 36(3), 187-196.

Sheppard, B.H., Hartwick, J., \& Warshaw, P.R. (1988). The Theory Of Reasoned Action - A MetaAnalysis Of Past Research With Recommendations For Modifications And Future-Research. Journal of Consumer Research, 15(3), 325-343. https://doi.org/10.1086/209170

Skawińska, E. (2010). Competitiveness Management: Monograph. Publishing House of Poznan University of Technology.

Štůsek, J., Kubata, K., \& Očenášek, V. (2017). Strategic Importance of the Quality of Information Technology for Improved Competitiveness of Agricultural Companies And Its Evaluation. AGRIS on-line Papers in Economics and Informatics, 9(4), 109-122. https://doi 10.7160/aol.2017.090411

Uggerslev, K.L., Fassina, N.E., \& Kraichy, D. (2012). Recruiting through the stages: A meta-analytic test of predictors of applicant attraction at different stages of the recruiting process. Personnel Psychology, 65(3), 597-660. https://doi.org/10.1111/j.1744-6570.2012.01254.x

Van Hoye, G. (2008). Nursing recruitment: Relationship between perceived employer image and nursing employees' recommendations. Journal of Advanced Nursing, 63(4), 366-375. https://doi.org/10.1111/j.1365-2648.2008.04710.x 


\section{Authors}

The contribution share of authors is $70 \%$ for the first author and $30 \%$ for the second author.

\section{Maria Rybaczewska}

Assistant professor at the University of Social Sciences in Łódź (Poland). Research Fellow at Stirling Management School, the University of Stirling (Scotland, UK). Her research interests include marketing, retail, HR, CSR, organizational communication, PR, and branding.

Correspondence to: Dr Maria Rybaczewska, University of Social Sciences in Łódź, ul. Sienkiewicza 9, 90-113 Łódź, Poland, e-mail: mrybaczewska@spoleczna.pl

ORCID (1) http://orcid.org/0000-0002-0098-1991

\section{Łukasz Sułkowski}

Full professor at Jagiellonian University in Kraków (Poland) and full professor at the University of Social Sciences in Łódź (Poland). His research interests include methodology, theory of organization, family business management, HR, marketing, and HEl's governance.

Correspondence to: Prof. Łukasz Sułkowski, PhD, Jagiellonian University, Faculty of Management and Social Communication, ul. Łojasiewicza 4, 30-348 Kraków, Poland, e-mail: lukasz.sulkowski@uj.edu.pl

ORCID (1) http://orcid.org/0000-0002-1248-2743

\section{Acknowledgements and Financial Disclosure}

The article is co-financed from the statutory scientific funds of the University of Social Sciences, Lodz, Poland.

\section{Copyright and License}

This article is published under the terms of the Creative Commons

Attribution - NoDerivs (CC BY-ND 4.0) License

http://creativecommons.org/licenses/by-nd/4.0/

Published by the Centre for Strategic and International Entrepreneurship - Krakow, Poland 